\title{
Raça e nacionalidade na biomedicina mexicana
}

\author{
Race and nationality in Mexican biomedicine
}

\author{
Vanderlei Sebastião de Souza \\ Professor do Departamento de História/Universidade Estadual do Centro-Oeste. \\ vanderleidesouza@yahoo.com.br
}

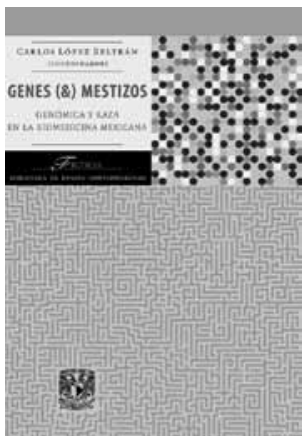

LÓPEZ BELTRÁN, Carlos

(Coord.). Genes (\&) mestizos: genómica y raza en la biomedicina mexicana. México: Ficticia, 2011. 358p. s estudos sobre genética de populações humanas têm sido realizados desde meados do século XX e, a partir do desenvolvimento das tecnologias de análises genômicas nas duas últimas décadas, vêm conquistando crescente destaque internacional. Desde então, bioantropólogos, geneticistas e médicos vêm desenvolvendo variados projetos de pesquisas voltados para o mapeamento genético de diferentes populações do mundo. O objetivo é não apenas estudar doenças influenciadas pela hereditariedade (como o diabetes, o câncer e problemas relacionados à hipertensão e à obesidade), as formas de prevenção, tratamento médico e produção de farmacogênicos, como também investigar a origem, a ancestralidade biológica dos grupos humanos e suas características genéticas identitárias.

Historicamente identificada como uma região 'multirracial', a América Latina é um dos lugares que mais têm atraído a atenção de cientistas e instituições interessadas em pesquisas sobre a diversidade genômica humana. Do ponto de vista da genética de populações, a região é vista como um verdadeiro 'laboratório racial', devido especialmente a sua diversidade biológica humana e seus variados aspectos geográficos e sociais. Estudos de genética de populações realizados em países como Brasil, Uruguai, Colômbia, Argentina e México vêm levantando uma série de polêmicas em torno da produção do conhecimento científico e do debate sobre raça e identidade étnica e social. No centro da questão encontra-se uma série de controvérsias envolvendo principalmente o uso das novas tecnologias genômicas para nomear diferenças e classificar a sociedade em 'grupos raciais' ou 'populacionais'.

Discussões como essas podem ser encontradas, por exemplo, no ambicioso projeto de mapeamento genético da população mexicana, lançado em 2004 pelo então recém-fundado Instituto Nacional de Medicina Genômica (Inmegen). Sustentado por recursos públicos e privados oriundos de diferentes instituições, o Inmegen foi criado justamente para promover 
o desenvolvimento tecnológico e científico ligado aos estudos sobre medicina genômica e a estrutura molecular da população do México. Tendo por justificativa a melhoria das condições de saúde pública, o projeto genoma mexicano colocou o país no centro de calorosas discussões sobre o uso das novas tecnologias genéticas e a dimensão ética e política envolvendo esse conhecimento.

O significado do projeto 'genoma mexicano', sobretudo no que diz respeito ao modo como a questão racial foi acionada pelo Inmegen, é o tema do livro Genes (\&) mestizos: genômica y raza em la biomedicina mexicana, publicado em 2011 sob a coordenação do filósofo e historiador das ciências Carlos López Beltrán, pesquisador do Instituto de Investigações Filosóficas da Universidade Nacional do México. O livro é resultado de discussões e seminários interdisciplinares promovidos, entre 2003 e 2010, por um grupo de pesquisadores mexicanos ligados aos estudos sobre história, filosofia e antropologia das ciências. A questão nevrálgica presente em Genes (\&) mestizos é a crítica à linguagem racializada empregada nos estudos de mapeamento genético da população mexicana. Os autores são unânimes em apontar o uso, por médicos e geneticistas, de categorias raciais, classificações e concepções de cunho ideológico que remeteriam à história oficial e aos discursos fundantes do Estado e da nacionalidade mexicana. Um exemplo disso seria o uso exaustivo da categoria 'raça mestiça' para nomear a população mexicana, cuja ancestralidade estaria associada especialmente à herança espanhola e indígena.

No imaginário popular mexicano, conforme os autores de Genes (\&) mestizos enfatizam em vários capítulos do livro, o México é caracterizado como uma nação amplamente miscigenada, tendo como símbolo da identidade nacional a figura do 'homem mestiço'. Nas narrativas acerca da história e da antropologia mexicana, a 'mestiçagem' envolvendo os colonizadores espanhóis e a população indígena, além de uma pequena parcela da população africana, é vista como um processo desejável e positivo, uma vez que integraria e harmonizaria as diferenças biológicas e sociais. Na introdução do livro, López Beltrán destaca que os geneticistas responsáveis pelo mapeamento genético mexicano não apenas teriam incorporado essa 'construção ideológica', reafirmando o papel da miscigenação na construção de uma autêntica identidade nacional, mas também a teriam reforçado a partir do emprego de seus pressupostos de investigação em genética populacional médica e antropológica. Ainda de acordo com esse autor, a imagem de um 'México mestiço' seria amplamente empregada pelos coordenadores do Inmegen como forma de conquistar a opinião pública e o apoio de lideranças políticas, de legitimar as novas tecnologias genômicas e, ao mesmo tempo, de nacionalizar a pesquisa científica mexicana.

Escrito sob perspectiva interdisciplinar, o livro está dividido em três seções temática que procuram tratar de diferentes aspectos envolvendo a relação entre ciência, raça, sociedade e o projeto 'genoma mexicano'. A primeira seção, "La ciência y el mestizo en la posrevolución", analisa o discurso de intelectuais e cientistas sobre a formação racial mexicana na primeira metade do século XX. No primeiro capítulo, a historiadora Marta Saade Granados faz uma interessante abordagem da construção do mestiço como símbolo da nacionalidade mexicana. Desde o final do século XIX, mas especialmente a partir da Revolução Mexicana, ocorrida no início do século XX, a imagem de um 'país mestiço' foi acionada como elemento constituinte da nação, alimentada tanto pelas autoridades políticas quanto por escritores, intelectuais e cientistas responsáveis por interpretar a 'evolução nacional'. 
Assim como ocorreu em outros países da América Latina, o Brasil entre eles, esse discurso servia como uma forma de reafirmar a homogeneidade e a singularidade da identidade nacional. A historiadora destaca que a maioria da intelectualidade do país assumiu a miscigenação como elemento de eugenização da 'raça mexicana', uma vez que eliminaria a 'herança patológica' oriunda de negros, índios, doentes e miseráveis.

$\mathrm{O}$ argumento de que a narrativa racial cumpre um papel central na história recente do México e na construção da identidade nacional também é problematizado no segundo capítulo do livro, de autoria de Edna Suárez Díaz e Ana Barahona Echeverría. Atentas para o contexto nacional e internacional do pós-Segunda Guerra Mundial, as autoras analisam o surgimento de novas tecnologias científicas empregadas entre os anos 1940 e 1960 para o estudo da genética humana. A partir da análise comparativa do desenvolvimento da genética de populações em países como os EUA, a Grã-Bretanha e o México, as pesquisadoras destacam que, além do uso das mesmas tecnologias (marcadores moleculares, técnicas sorológicas e imunológicas), os interesses de pesquisas também coincidiam, consistindo no conhecimento das variantes genéticas dos diferentes povoamentos do território nacional, com fins de investigação médica e clínica, assim como estudos de ancestralidade dos 'grupos mestiços' e ameríndios. Por fim, Díaz e Echeverría concluem que, apesar do uso de diferentes recursos conceituais, políticos e materiais, a 'antropologia molecular' mexicana do pós-Segunda Guerra Mundial, continuou utilizando categorias tipológicas semelhante àquelas empregadas pela antropologia física em períodos anteriores.

A análise mais detida sobre o Instituto de Medicina Genômica do México é realizada na segunda seção do livro, que Carlos López Beltrán e Francisco Vergara Silva abrem abordando o 'espaço ideológico e político' dentro do qual se desenvolveu o projeto genoma mexicano. Para esses autores, a linguagem utilizada pelo Inmegen transcendeu o âmbito da medicina e da saúde pública e adentrou questões ideológicas e retóricas relacionadas à história, à identidade nacional e aos interesses da nação. Ao assumir "que o mestiço mexicano tinha uma estirpe genomicamente peculiar e suficientemente diferente de outras regiões" (p.103; tradução livre), os pesquisadores não apenas ignoraram a presença de outras minorias étnicas, como também reafirmaram o discurso histórico e ideológico acerca da formação nacional. Isso implicava, entre outras coisas, afirmar que o país tem uma singular característica racial e que vive etnicamente em harmonia. Implicava ainda acionar o sentimento nacionalista como forma de conquistar apoio e legitimidade social para o desenvolvimento dessas pesquisas. Como consequência, os autores entendem que a estratégia reduziu a possibilidade do debate público em torno da racialização da sociedade e dos caminhos da investigação genômica no país. Por último, não deixam de destacar que os pesquisadores do Inmegen decidiram abordar questões ligadas à genética de povoamento, demografia histórica e antropologia física, sem perceber a princípio as dificuldades de introduzir esses temas em suas investigações.

Nos dois capítulos seguintes, Vivette García Deister e Ernesto Schwartz Marín analisam, a partir de pesquisas etnográficas em laboratórios, o modo como o tema da 'mestiçagem' é tratado nos estudos sobre genoma humano. Em seu artigo, Deister procura demonstrar a fragilidade conceitual existente nos trabalhos de antropologia molecular, sobretudo no que diz respeito ao emprego da taxonomia racial. A autora aponta como exemplo dessa imprecisão conceitual o emprego da categoria 'mestiço', que nos estudos de geneticistas do 
Inmegen teriam recebido diferentes definições. Ernesto Marín, por sua vez, analisa o modo como o projeto de mapeamento genético mexicano ajudou no processo de materialização e reificação da identidade nacional, reativando noções comuns amplamente difundidas sobre o 'mestiço', a 'mestiçagem' e a nacionalidade mexicana. O último capítulo dessa seção, de autoria de Fabrizzio Guerrero McManus, problematiza a questão do valor da origem mestiça mexicana e o modo como o projeto genoma lidou com a ideia da ancestralidade, da unicidade e da diversidade étnica. Fazendo coro a um dos argumentos centrais do livro, o autor explica que a ênfase de geneticistas sobre a unicidade genômica do mestiço mexicano não levou em consideração o fato de que essa interpretação é construída a partir de um espaço simbólico que esconde a diversidade étnica do país.

A última seção de Genes (\&) mestizos trata mais especificamente dos conceitos e dos métodos classificatórios empregados pelo Inmegen. Carlos Galindo abre a seção analisando as categorias raciais utilizadas nos censos populacionais de alguns países, entre eles Brasil, México, Canadá e EUA, para apontar a dificuldade e a arbitrariedade no uso de classificações raciais ou étnicas. $\mathrm{O}$ autor procura demonstrar que todos os censos empregam categorias raciais muito particulares, que na maioria das vezes correspondem ao imaginário social específico de cada país. O mesmo teria ocorrido na terminologia empregada no projeto 'genoma mexicano', que de acordo com Galindo não corresponderia às definições genéticas, mas sim à percepção social. No capítulo dois, Rasmus G. Winther problematiza, por sua vez, o uso dos métodos matemáticos nos estudos de genética, atentando para os perigos das abstrações científicas, como a reificação da 'genética das raças'.

Argumentos semelhantes ao de Galindo podem ser encontrados nos capítulos três e quatro dessa seção, escritos por Yuriditzi Pascacio Montijo e Alfonso Arroyo Santos, respectivamente. De acordo com Montijo, as classificações de populações empregadas pelo Inmegen não se basearam em fenótipos observáveis, mas antes em diversas categorizações preestabelecidas, como aquelas empregadas na divisão política do Estado mexicano, construídas a partir da existência de subpopulações, como se pode perceber, por exemplo, no caso dos estados de Sonora, Zacoteca, Veracuz e Yucatán. Nesse sentido, advertindo para a arbitrariedade das classificações raciais, o autor conclui com o seguinte questionamento: há necessidade de lançar mão da genotipificação da população em estudos sobre saúde e enfermidades? E, de outro lado, é possível afirmar que existe, de fato, 'enfermidades nacionais'? No capítulo seguinte, partindo das duas principais premissas que nortearam o Inmegen (a de que devido a um processo histórico particular a população mexicana é geneticamente miscigenada; e que por conta dessa singularidade o mestiço é suscetível a certas enfermidades), Alfonso Arroyo Santos também analisa a fragilidade epistemológica da construção genética acerca dos mestiços mexicanos.

Como se pode perceber, Genes (\&) mestizos nos convida a uma reflexão crítica sobre o significado da 'genetização' da sociedade e o uso de classificações para nomear diferenças raciais, étnicas e sociais. Como os autores desse livro apontam, a genética médica é uma promessa que poderá trazer inúmeros benefícios para a saúde pública; a questão é saber se o uso de uma linguagem racializada e classificatória para esse fim, conforme transparece no projeto genoma mexicano, não trará consequências políticas e éticas perigosas, como o risco de continuar repetindo divisões sociais e exclusões de minorias étnicas. Por último, é importante 
ressaltar que o livro é uma boa indicação de leitura para os pesquisadores interessados nas discussões sobre ciência, raça e sociedade em contexto latino-americano, uma vez que abre a possibilidade para diferentes análises comparativas.

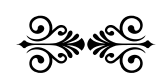

